\title{
Comorbid neuropathologies in migraine: an update on cerebrovascular and cardiovascular aspects
}

\author{
Simona Sacco $\cdot$ Davide Cerone $\cdot$ Antonio Carolei
}

Received: 11 April 2008/ Accepted: 3 June 2008/Published online: 4 July 2008

(C) Springer-Verlag 2008

\begin{abstract}
Several conditions are comorbid with migraine; our review is focused on the relation between migraine, and cerebrovascular and cardiovascular diseases. Despite many studies showed an association between migraine and patent foramen ovale, it is still not known whether its presence might be causal for the migraine pathogenesis and currently its closure cannot be recommended for migraine prevention. On the contrary, conflicting epidemiological data link migraine to arterial hypertension and the use of antihypertensive agents acting on the renin-angiotensin system sounds promising in migraine prevention. A complex bidirectional relation exists between migraine and stroke, and new evidences show a clear association between migraine and coronary heart disease. In both conditions, migraine represents a defined risk factor although the magnitude of the risk varies across the different studies. However, since the risk is low in the general population, it is not possible to identify which migraineurs will develop a cardiovascular or a cerebrovascular event making difficult to apply preventive measures.
\end{abstract}

Keywords Migraine - Patent forame ovale .

Arterial hypertension - Retinal disease .

Cardiovascular disease - Cerebrovascular disease .

Stroke $\cdot$ Myocardial infarction

As reported in the literature, comorbidity may be defined as the presence of any additional coexistent condition in a

S. Sacco · D. Cerone · A. Carolei $(\bowtie)$

Department of Neurology, University of L'Aquila,

Piazzale Salvatore Tommasi, 1, 67010 L'Aquila, Italy

e-mail: a_carolei@yahoo.com patient with an index disease or as an association between two different disorders that is more than coincidental [1]. According to Lipton and Silberstein [2] comorbidity may arise by coincidence or selection bias, one condition may cause the other, both conditions may be related to shared environmental genetic risk factors, and the same environmental or genetic risk factors may determine a brain state that gives rise to both conditions. The presence of a comorbidity may complicate the diagnosis because of the overlapping symptoms [2].

We already reviewed the comorbid neuropathologies in migraine [3]; this update includes the most recent advances on cerebrovascular and cardiovascular comorbidities.

\section{Migraine and patent foramen ovale}

Patent foramen ovale (PFO), an interatrial communication remnant of the fetal circulation, is due to the failure in the fusion of the septum primum with the septum secundum. Anatomically, the PFO comprises overlapping portions of septum primum and septum secundum, acting as a 1-way flap valve allowing right-to-left shunt when the pressure in the right atrium is superior to the pressure in the left atrium $[4,5]$. The prevalence of PFO in the healthy adult population is around $25 \%$. Since the last decade evidences cumulated showing that migraine and PFO are associated to an extent that goes beyond what would be predicted by the chance co-occurrence of two common conditions. In casecontrol studies, migraine with aura has been found to be associated with PFO in nearly $50 \%$ of cases that is twice the figure usually reported in non-migraineurs [6-10] and in patients with PFO migraine has been found twice as frequently as in patients without PFO [11-13]. Right-to-left cardiac shunt at rest through a PFO is more common in 
migraineurs with aura than in non-migraineurs control patients with PFO [6] and patients with migraine tend to have greater right-to-left shunts with respect to the nonmigrainous population [10] suggesting that interatrial communication may play a role in the pathogenesis of migraine. The mechanisms underlying this possible association have been postulated but never demonstrated. Venous blood contains agents normally removed by passage through the lungs that can trigger an attack of migraine if they reach the brain in sufficient concentrations; alternatively, long-term shunting of those agents may reduce the threshold for migraine generation in the brain [14]. Such observations do not obviously imply that PFO is the cause of migraine, as only $50 \%$ of patients with migraine with aura exhibit PFO and not all subjects with PFO have migraine. However, patients with migraine who have large right-to-left shunts tend to recognize those activities that increase the extent of the shunt as a trigger of their migraine attacks suggesting that the PFO might play a relevant role in subjects with a constitutional susceptibility to migraine [15]. Not all studies, however, support this hypothesis. The recent Shunt-Associated Migraine (SAM) study showed that the effect of right-to-left shunt on migraine features is not relevant but patients with shunt-associated migraine had a higher likelihood to have at least one first degree relative affected by migraine suggesting a possible genetic linkage between migraine and PFO [16]. Clarifying if a PFO plays any role in migraine pathogenesis or if the association is caused by a common inheritance but is not causal for migraine is crucial. If the former hypothesis will be proved, trials of PFO closure for migraine prevention would have a rationale, in the latter case there will be no reason to close the PFO to prevent migraine.

\section{Closure of the PFO for migraine prevention}

A variable proportion of patients who underwent $\mathrm{PFO}$ closure for non-migraine indications reported cessation or improvement of their migraine attacks after the procedure [17-29] (Table 1). The effect was evident for patients with migraine with (frequency reduced by 54\%) or without (frequency reduced by 62\%) aura but not for patients with non-migraine headaches [27]. Those studies are limited by being predominantly retrospective, non-randomized, and conducted in highly selected populations of patients. Furthermore, the highly variable course of migraine and the known placebo effect in previous migraine trials preclude any conclusion.

The Migraine Intervention with STARFlex Technology (MIST) trial was the first randomized controlled study designed to assess the effect of PFO closure on migraine headache in patients with frequent, disabling, and drugresistant migraine with aura [30]. In the trial, patients who suffered from migraine with aura, experienced frequent migraine attacks, had previously failed 2 or more classes of prophylactic treatments, and had moderate or large rightto-left shunts consistent with the presence of a PFO, were randomized to transcatheter PFO closure with the STARFlex implant or to a sham procedure. Patients were followed up for 6 months. The primary efficacy end point was cessation of migraine headache 91 to 180 days after the procedure. One hundred forty-seven patients were randomized. No significant difference was observed in the primary end point of migraine headache cessation between implant and sham groups ( 3 of 74 versus 3 of 73, respectively; $P=0.51$ ). Secondary end points also were not achieved. On exploratory analysis, excluding two outliers, the implant group demonstrated a greater reduction in total migraine headache days $(P=0.027)$. As expected, the implant arm experienced more procedural serious adverse events; all events were transient. However, the results of the MIST trial did not allow to definitely exclude any benefit of the PFO closure. In fact, the included patients were selected because they had particularly severe and refractory migraine that is less amenable to treat than mild or moderate migraine; the continued use of prophylactic migraine medication throughout the trial in both treatment arms may have limited the impact of PFO closure; and the primary study end point of migraine cessation may have been unrealistic and less clinically relevant than reduction in migraine frequency since even the best-designed studies of preventive medications show a responder rate (reduction of migraine frequency $\geq 50 \%$ ) of only around 50\% [31]. According to the SAM study the presence of a right-to-left shunt reduced the susceptibility to develop a migraine attack following exposure to other triggers but enhanced the likelihood of initiating an attack with an aura [16]; consequently, it should be tested the hypothesis whether PFO closure may benefit auras rather than pain in migraineurs. Finally, in the MIST trial, the benefits of PFO closure were analyzed from 3 to 6 months after device implant. The effect of PFO closure during this relatively early analysis phase may have been confounded by clopidogrel use, incomplete closure of the defect, concomitant pulmonary shunt, and a possible early transient adverse effect of device implant. Therefore, a longer analysis phase might have demonstrated additional benefit accrued over time. Residual shunts were assessed by the investigators using contrast transthoracic echocardiography at 6 months. However, it is likely that more residual shunts persisted earlier during the analysis phase and atrial or pulmonary shunts below the detection threshold of this technique might have had an impact on the treatment effect in this population.

Thus, there is insufficient evidence on the hypothesis that migraine frequency is reduced by PFO closure. Further 
Table 1 Effect of patent foramen ovale closure on migraine in non-randomized studies in which the closure was performed for other reasons than migraine

\begin{tabular}{|c|c|c|c|c|c|c|c|}
\hline \multirow[t]{2}{*}{ Study } & \multirow[b]{2}{*}{$\begin{array}{l}\text { Time to } \\
\text { assessment }\end{array}$} & \multicolumn{2}{|c|}{ Patients reporting cessation $(\%)$} & \multicolumn{2}{|c|}{ Patients reporting improvement $(\%)$} & \multicolumn{2}{|c|}{ Patients reporting no effect $(\%)$} \\
\hline & & $\begin{array}{l}\text { Migraine } \\
\text { with aura }\end{array}$ & $\begin{array}{l}\text { Migraine } \\
\text { without aura }\end{array}$ & $\begin{array}{l}\text { Migraine } \\
\text { with aura }\end{array}$ & $\begin{array}{l}\text { Migraine } \\
\text { without aura }\end{array}$ & $\begin{array}{l}\text { Migraine } \\
\text { with aura }\end{array}$ & $\begin{array}{l}\text { Migraine } \\
\text { without aura }\end{array}$ \\
\hline Anzola [17] & 1 year & 34 & 41 & 53 & 47 & 13 & 12 \\
\hline Azarbal [19] & 3 months & 75 & 40 & 5 & 40 & 20 & 20 \\
\hline Giardini $[20]$ & 1.7 years & 83 & - & 9 & - & 8 & - \\
\hline Post [23] & 6 months & 75 & 57 & NR & NR & NR & NR \\
\hline Reisman [24] & 37 weeks & 54 & 62 & 14 & 15 & 32 & 23 \\
\hline Rigatelli [25] & 11 months & 100 & - & 0 & - & 0 & - \\
\hline Schwerzmann [27] & 1 year & NR & NR & 79 & 90 & 21 & 10 \\
\hline Wilmshurst [28] & 17 months & 44 & 60 & 50 & 0 & 6 & 40 \\
\hline
\end{tabular}

$N R$ not reported

properly conducted, prospective studies in migraine patients including control groups with other or no headaches are underway in Europe and USA. Until then PFO closure should not be used for the prophylaxis of migraine [32].

\section{Migraine and arterial hypertension}

Despite the possible association between migraine and arterial hypertension is an old issue, data still do not prove an univocal interpretation of the co-occurrence of these two conditions. In fact, several studies have explored a possible association between migraine and hypertension, with contradictory results. Some studies have shown a positive association between migraine and hypertension [33-37], others found no association while others found a negative association between migraine and hypertension [38-47] (Table 2). This fact may be attributed to differences in methodology, the small sample size of some studies and to some diagnostic inaccuracy in the characterization of the various headache forms including migraine. Confusion may arise also from the fact that hypertension may be an epiphenomenon of acute pain while, headache may be associated with hypertensive encephalopathy as a consequence of increased intracranial pressure, or may be reported as a side effect of some antihypertensive treatments.

Antihypertensives for migraine prophylaxis

Beta-blockers that are drugs capable of lowering blood pressure have been extensively used for migraine prevention. More recently, drugs acting on the renin-angiotensin system such as the angiotensin converting enzyme inhibitors and the angiotensin II receptor blockers, have been tested in migraine prophylaxis.
A double blind, placebo controlled, crossover study of lisinopril $10 \mathrm{mg} /$ day in 60 patients with migraine aged 1959 years with two to six episodes per month showed that active treatment had a clinically important prophylactic effect in migraine [48]. Hours with headache, days with headache, days with migraine, and headache severity index were reduced by $20,17,21$, and $20 \%$, respectively, with lisinopril compared with placebo. Days with migraine were reduced by at least $50 \%$.

A randomized, double-blind, placebo-controlled crossover study of candesartan $16 \mathrm{mg} /$ day in 60 migrainous patients showed that the angiotensin II receptor blocker provided effective migraine prophylaxis, with a tolerability profile comparable with that of placebo. In detail, candesartan reduced the number of days with headache including hours with headache, days with migraine, hours with migraine, headache severity index, levels of disability and days of sick leave although there were no differences in health-related quality of life [49].

Another small, open-label study showed that patients with migraine and arterial hypertension or prehypertension treated with olmesartan (10-40 mg/day) for at least 3 months reported an $82.5 \%$ average reduction in the frequency of migraine attacks [50]. Patients also experienced a $45 \%$ average reduction in the severity of migraine attacks measured on a numeric pain scale of 1-10 [50]. Further studies are needed to confirm the possible benefits of olmesartan in patients with migraine.

The mechanisms underlying the benefits of drugs acting on the renin-angiotensin system for migraine prophylaxis are unknown. Whether the prevention of migraine is attributable to the blood pressure reduction or to separate pharmacological actions of the drugs other than lowering blood pressure is still an unresolved issue. Angiotensin II is a vasoconstrictor agent, increases sympathetic discharge and adrenal medullary catecholamine release. Angiotensin 
Table 2 Selected studies evaluating the association between blood pressure, arterial hypertension and migraine

\begin{tabular}{|c|c|c|c|c|}
\hline Study & Design & $\begin{array}{l}\text { Diagnosis of } \\
\text { migraine }\end{array}$ & Evaluation of BP & Results \\
\hline Cirillo [33] & $\begin{array}{l}\text { Cohort study (age } \\
16-64 \text { years) }\end{array}$ & ICHD-I criteria & $\begin{array}{l}\text { Hypertension defined as } \\
\text { SBP } \geq 140 \mathrm{mmHg} \text { and/or } \\
\mathrm{DBP} \geq 90 \mathrm{mmHg} \text { and/or use of } \\
\text { antihypertensives }\end{array}$ & $\begin{array}{l}\text { Association between arterial } \\
\text { hypertension and headache } \\
\text { (including migraine) in men and } \\
\text { women }\end{array}$ \\
\hline $\begin{array}{l}\text { Gudmundsson } \\
\text { [39] }\end{array}$ & $\begin{array}{l}\text { Population-based } \\
\text { study }\end{array}$ & $\begin{array}{l}\text { ICHD-I criteria } \\
\text { modified }\end{array}$ & $\begin{array}{l}\text { Measurement of blood pressure. } \\
\text { Hypertension defined as } \\
\mathrm{SBP} \geq 160 \mathrm{mmHg} \text { and/or } \\
\mathrm{DBP} \geq 95 \mathrm{mmHg} \text { and/or use of } \\
\text { antihypertensives }\end{array}$ & $\begin{array}{l}\text { No association between } \\
\text { hypertension and migraine. } \\
\text { Increased probability of having } \\
\text { migraine with increasing DBP } \\
\text { for women and decreased } \\
\text { probability of having migraine } \\
\text { with increasing SBP in men and } \\
\text { women }\end{array}$ \\
\hline Hagen [40] & $\begin{array}{l}\text { Population-based } \\
\text { study }\end{array}$ & $\begin{array}{l}\text { ICHD-I criteria } \\
\text { modified }\end{array}$ & Measurement of blood pressure & $\begin{array}{l}\text { Trend for decreased probability of } \\
\text { having migraine for higher SBP } \\
\text { in women but not in men. No } \\
\text { association between DBP and } \\
\text { migraine }\end{array}$ \\
\hline Muiesan [41] & $\begin{array}{l}\text { Population-based } \\
\text { study (age } \\
35-50 \text { years) }\end{array}$ & ICHD-I criteria & $\begin{array}{l}\text { Measurement of blood pressure. } \\
\text { Hypertension defined as } \\
\text { SBP } \geq 140 \mathrm{mmHg} \text { and/or } \\
\text { DBP } \geq 90 \mathrm{mmHg} \text { and/or use of } \\
\text { antihypertensives }\end{array}$ & $\begin{array}{l}\text { No association between migraine } \\
\text { and arterial hypertension }\end{array}$ \\
\hline Prudenzano [42] & Cohort study & ICHD-II criteria & $\begin{array}{l}\text { Hypertension defined as } \\
\mathrm{BP}>140 / 80 \mathrm{mmHg}\end{array}$ & $\begin{array}{l}\text { Lower prevalence of hypertension } \\
\text { in migraine than in tension-type } \\
\text { headache }\end{array}$ \\
\hline Tronvik [44] & $\begin{array}{l}\text { Population-based } \\
\text { study }\end{array}$ & $\begin{array}{l}\text { ICHD-I criteria } \\
\text { modified }\end{array}$ & Measurement of blood pressure & $\begin{array}{l}\text { Increasing SBP was associated } \\
\text { with decreasing prevalence of } \\
\text { having migraine. For DBP, the } \\
\text { findings were less consistent }\end{array}$ \\
\hline Tzourio [46] & $\begin{array}{l}\text { Population-based } \\
\text { study (age } \\
\text { 59-71 years) }\end{array}$ & ICHD-I criteria & $\begin{array}{l}\text { Measurement of blood pressure. } \\
\text { Hypertension defined as } \\
\mathrm{SBP} \geq 140 \mathrm{mmHg} \text { and/or } \\
\mathrm{DBP} \geq 90 \mathrm{mmHg} \text { and/or use of } \\
\text { antihypertensives }\end{array}$ & $\begin{array}{l}\text { Migraineurs had a lower mean } \\
\text { SBP than non migraineurs, a } \\
\text { lower pulse pressure, and a } \\
\text { lower mean DBP, although the } \\
\text { difference was not significant } \\
\text { for the latter. Significant trend } \\
\text { of decreasing frequency of } \\
\text { migraine with increasing blood } \\
\text { pressure }\end{array}$ \\
\hline Wiehe [47] & $\begin{array}{l}\text { Population-based } \\
\text { study }\end{array}$ & ICHD-I criteria & $\begin{array}{l}\text { Hypertension defined as } \\
\mathrm{SBP} \geq 140 \mathrm{mmHg} \text { and/or } \\
\mathrm{DBP} \geq 90 \mathrm{mmHg} \text { and/or use of } \\
\text { antihypertensives }\end{array}$ & $\begin{array}{l}\text { Migraine was less frequent among } \\
\text { participants with hypertension. } \\
\text { SBP and DBP were lower in } \\
\text { migraineurs }\end{array}$ \\
\hline
\end{tabular}

$B P$ blood pressure; $S B P$ systolic blood pressure; $D B P$ diastolic blood pressure; $I C H D$ International Classification Headache Disorders

is also involved in local brain functions mediated by the type I receptors that include modulation of the cerebrovascular flow, effects on fluids and electrolyte homeostasis, autonomic pathways, and neuroendocrine systems.

\section{Migraine and cerebrovascular and cardiovascular diseases}

There are evidences that link migraine with ischemic stroke and ischemic heart disease and potential mechanisms accounting for their association. The association between migraine and vascular disease of the retina has been also reported.

Migraine and stroke

A complex bidirectional relation exists between migraine and stroke including migraine as a risk factor for stroke, migraine caused by stroke, migraine as a cause of stroke, migraine and stroke sharing a common cause, migraine mimicking stroke, and migraine associated with subclinical 
Table 3 Possible comorbidities between migraine and stroke

\begin{tabular}{|c|c|c|c|c|c|c|}
\hline \multicolumn{3}{|l|}{ Type } & \multicolumn{4}{|l|}{ Definition } \\
\hline \multicolumn{3}{|c|}{ Migraine as a risk factor for stroke } & \multicolumn{4}{|c|}{$\begin{array}{l}\text { A clearly clinically defined stroke syndrome must occur remotely in time from a typical attack } \\
\text { of migraine }\end{array}$} \\
\hline \multicolumn{3}{|c|}{$\begin{array}{l}\text { Migraine caused by stroke (symptomatic } \\
\text { migraine) }\end{array}$} & \multicolumn{4}{|c|}{$\begin{array}{l}\text { An acute vascular event in the central nervous system (ischemic or hemorrhagic stroke or TIA) } \\
\text { produces episodes of headache with the characteristics of migraine with or without aura; to } \\
\text { be coded as ICHD-II } 6.1\end{array}$} \\
\hline \multicolumn{3}{|c|}{$\begin{array}{l}\text { Migraine as a cause of stroke (migrainous } \\
\text { infarction) }\end{array}$} & \multicolumn{4}{|c|}{$\begin{array}{l}\text { A documented infarct in a relevant area during the course of an attack of migraine with aura, in } \\
\text { a patient with a history of migraine with aura, with symptoms that are those of the aura and } \\
\text { in the absence of other possible causes at an extensive workup; to be coded as ICHD-II } 1.5 .4\end{array}$} \\
\hline \multicolumn{3}{|c|}{ Migraine and stroke sharing a common cause } & \multicolumn{4}{|c|}{$\begin{array}{l}\text { A syndrome (usually of genetic origin) in which both migraine and stroke are major clinical } \\
\text { features (e.g. CADASIL [ICHD-II 6.7.1] or MELAS [ICHD-II 6.7.2]) }\end{array}$} \\
\hline \multicolumn{3}{|c|}{ Migraine associated with subclinical stroke } & \multicolumn{4}{|c|}{$\begin{array}{l}\text { Evidence at brain neuroimaging of small areas compatible with brain ischemia in patients } \\
\text { without a history of any clinical symptom indicating a stroke syndrome }\end{array}$} \\
\hline \multicolumn{3}{|c|}{$\begin{array}{l}\text { Migraine mimicking stroke (and viceversa: } \\
\text { stroke mimicking migraine) }\end{array}$} & \multicolumn{4}{|c|}{$\begin{array}{l}\text { Symptoms of migraine attacks (particularly aura without headache) and of stroke (particularly } \\
\text { TIAs) may overlap causing problems in the differential diagnosis }\end{array}$} \\
\hline \multicolumn{7}{|c|}{$\begin{array}{l}\text { TIA transient ischemic attack, ICHD-II International Classification of Headache Disorders, Second Edition; CADASIL Cerebral Autosomal } \\
\text { Dominant Arteriopathy with Subcortical Infarcts and Leucoencephalopathy; MELAS Mitochondrial Encephalopathy, Lactic Acidosis and Stroke- } \\
\text { like episodes }\end{array}$} \\
\hline Study & $\begin{array}{l}\text { Age } \\
\text { (years) }\end{array}$ & Sex & $\begin{array}{l}\text { Total sample } \\
(n)\end{array}$ & $\begin{array}{l}\text { Any migraine } \\
(\mathrm{RR}, 95 \% \mathrm{CI})\end{array}$ & $\begin{array}{l}\text { Migraine with aura } \\
(\mathrm{RR}, 95 \% \mathrm{CI})\end{array}$ & $\begin{array}{l}\text { Migraine without aura } \\
(\mathrm{RR}, 95 \% \mathrm{CI})\end{array}$ \\
\hline Buring $[52]^{\mathrm{a}, \mathrm{c}}$ & $40-84$ & M & 22,071 & $2.0,1.1-3.6$ & NR & NR \\
\hline Carolei $[53]^{\mathrm{a}, \mathrm{d}}$ & $15-44$ & $\mathrm{M}, \mathrm{W}$ & 899 & $1.3,0.7-2.4$ & $8.6,1.0-75$ & $1.0,0.5-2.0$ \\
\hline Chang $[54]^{\mathrm{a}, \mathrm{c}}$ & $20-44$ & $\mathrm{~W}$ & 1,027 & $3.5,1.3-9.6$ & $3.8,1.3-11.5$ & $3.0,0.7-13.5$ \\
\hline Henrich $[59]^{\mathrm{a}, \mathrm{d}}$ & $15-65$ & $\mathrm{M}, \mathrm{W}$ & 267 & $1.8,0.9-3.6$ & $2.6,1.1-6.6$ & $1.3,0.5-3.6$ \\
\hline Kurth $[60]^{\mathrm{a}, \mathrm{c}}$ & $\geq 45$ & $\mathrm{~W}$ & 39,754 & $1.4,1.0-1.9$ & $1.7,1.1-2.7$ & $1.1,0.7-1.8$ \\
\hline MacClellan [62] ${ }^{\mathrm{a}, \mathrm{c}}$ & $15-49$ & $\mathrm{~W}$ & 1,000 & NR & $1.5,1.1-2.0$ & $1.0,0.6-1.5$ \\
\hline Marini $[63]^{\mathrm{a}, \mathrm{d}}$ & $15-44$ & $\mathrm{M}, \mathrm{W}$ & 616 & NR & $14.8,1.8-124$ & $1.6,0.9-3.0$ \\
\hline Merikangas [64] $]^{\mathrm{b}, \mathrm{c}}$ & $25-74$ & $\mathrm{M}, \mathrm{W}$ & 12,220 & $2.1,1.5-2.9$ & NR & NR \\
\hline Nightingale $[67]^{\mathrm{a}, \mathrm{c}}$ & $15-49$ & $\mathrm{~W}$ & 1,319 & $2.3,1.0-5.2$ & NR & NR \\
\hline Schwaag $[68]^{\mathrm{a}, \mathrm{d}}$ & $\leq 45$ & $\mathrm{M}, \mathrm{W}$ & 320 & $2.1,1.2-3.8$ & NR & NR \\
\hline Stang $[70]^{\mathrm{a}, \mathrm{c}}$ & $45-64$ & $\mathrm{M}, \mathrm{W}$ & 12,750 & NR & $2.7,1.6-4.6$ & $0.8,0.4-1.5$ \\
\hline Tzourio $[71]^{\mathrm{a}, \mathrm{d}}$ & $18-80$ & $\mathrm{M}, \mathrm{W}$ & 424 & $1.3,0.8-2.3$ & $1.3,0.5-3.8$ & $0.8,0.4-1.5$ \\
\hline Tzourio $[72]^{\mathrm{a}, \mathrm{c}}$ & $<45$ & $\mathrm{~W}$ & 245 & $3.5,1.8-6.4$ & $6.2,2.1-18.0$ & $3.0,1.5-5.8$ \\
\hline
\end{tabular}

$N R$ not reported; $M$ men; $W$ women

a Studies including only ischemic strokes

b Studies including ischemic and hemorrhagic strokes

c Adjusted risk

${ }^{\mathrm{d}}$ Unadjusted risk

stroke $[3,51]$. Such possibilities were already extensively reviewed and are summarized in Table 3 [3].

Numerous studies evaluated the association between migraine and risk of stroke (Table 4) [51-72]. There is good evidence that migraine with aura is associated with an increased risk of ischemic stroke while data do not support an univocal association between migraine without aura and ischemic stroke [53]. The risk of stroke among migraineurs is especially increased in young women with migraine with aura, but is also apparent in older individuals. The increased severity of the migraine attack is not associated with an increased risk of ischemic stroke; on the contrary, high frequency of attacks ( $>12$ attacks per year) and a recent onset of migraine (lifetime duration of $<1$ year before the stroke event) are related to an increased risk [62]. The risk of stroke in migraineurs is increased of more than three times in the presence of cigarette smoking and of more than four times in the presence of oral contraceptive 
use $[54,72]$. The combination of migraine, oral contraceptives, and smoking further increases the risk [54]. More recent findings suggest that neither oral contraceptive use nor smoking alone substantially increase the odds ratio of ischemic stroke among women with migraine with aura [62]. However, the combination of both, results in a tenfold increased risk of ischemic stroke when compared with women without migraine who did not smoke and did not use oral contraceptives [62], which is consistent with previous observations. Those data strongly indicate that women with migraine with aura who use oral contraceptives should be strictly advised to quit smoking. Although limited by small numbers, data indicate that the presence of a PFO did not substantially increase the risk of ischemic stroke among women with migraine with aura [62], suggesting that its presence is unlikely to explain a large amount of strokes in migraineurs. With regard to ischemic stroke subtypes, the proportion of lacunar infarction and of ischemic stroke of undetermined origin but not of atherosclerotic and cardioembolic strokes was higher among women with migraine with aura than in non-migraine stroke patients [62] suggesting possible alternative pathogenic mechanisms in migraineurs.

Migraine may directly cause a cerebral ischemic event (migrainous infarction, ICHD-II 1.5.4) [73]. This condition is very rare and vastly over diagnosed [73]. Migrainous infarction is considered a direct consequence of an unusually severe hypoperfusion during the aura. To diagnose migraine-induced stroke the neurological deficit must exactly mimic the migrainous symptoms of previous attacks; the stroke must occur during the course of a typical migraine attack; all other causes of stroke must be excluded although stroke risk factors may be present [73]. Since most strokes in migraineurs do not occur during the course of migraine attack, this condition may account only for a minority of strokes in migraineurs and may not account for the increased risk of non cerebral events.

Migraine has also been associated with subclinical vascular brain lesions [74, 75]. These lesions appear as infarcts on magnetic resonance imaging even in the absence of a clinical history of stroke. Lesions are particularly common in the posterior circulation vascular territory [76-79]. Even in the absence of differences between patients with migraine and controls in the overall infarct prevalence ( 8.1 vs. $5.0 \% ; P=0.23), 8.1 \%$ of patients with migraine with aura compared with $2.2 \%$ of patients with migraine without aura and $0.7 \%$ of controls $(P=0.05)$ had one or more lesions in the cerebellar region [74]. Participants at the highest risk were those with migraine with aura and at least one attack per month compared with controls [74]. Traditional cardiovascular risk factors and specific antimigraine medications did not modify the association between structural brain changes and migraine [74]. Specific small cerebellar border zone infarct-like lesions were those mostly represented [75]. Patients with and without posterior circulation territory infarct-like lesions did not present differences in cardiovascular risk factors [75] suggesting that, when present, such lesions are not atherosclerotic in origin or reflect small-vessel disease and that a combination of (possibly migraine-related) hypoperfusion and embolism is the likeliest etiological mechanism, although other mechanisms could also play a role.

Migraine and retinal vascular disease

Case reports have linked retinal vein occlusions $[80,81]$ and retinal infarctions $[82,83]$ to migraine. A populationbased study in a white Australian population (age 49 years and older) reported smaller retinal arteriolar calibers among persons with a history of migraine without aura as compared with those without a history of migraine [84]. Recent results from the Atherosclerosis Risk in Communities (ARIC) Study indicate that middle-aged persons with migraine and other headaches and without arterial hypertension and diabetes mellitus were more likely to have retinopathy signs including retinal hemorrhages (blot or flame shaped), microaneurysms, soft or hard exudates, macular edema, intraretinal microvascular abnormalities, venous beading, swelling, or laser photocoagulation scars [85]. The association was stronger in patients with migraine with aura.

The retinal and cerebral microcirculations share similar anatomy, embryology, and physiology. Since the retina is more accessible than cerebral vessels, understanding the mechanisms of the vascular disease of the retina might provide important clues to clarify the relation between stroke and migraine.

\section{Migraine and coronary heart disease}

While increased risk of ischemic stroke among persons with migraine, and particularly with migraine with aura, has been well established, the association between migraine with aura and overall cardiovascular disease including coronary heart disease has been long debated [86-94]. Only recently, a clear association between migraine and cardiovascular disease became evident $[88$, 89, 92].

A large cohort of more than 12,000 individuals participating in the ARIC study found an association between migraine, and particularly migraine with aura, with Rose angina that in the absence of a corresponding association with coronary artery disease suggested that the association between migraine and angina was not mediated by coronary artery disease [92]. However, the ARIC study did not 
allow any conclusive evidence mostly due to a possible bias related to the assessment of the headaches.

A prospective cohort of the Women's Health Study which included 27,840 US women aged 45 years or older and that were free of cardiovascular disease and angina at study entry showed that, after a mean of 10 years of follow-up, active migraine with aura was associated with an increased risk of cardiovascular events while the association was not evident for patients suffering from migraine without aura [88]. In detail, compared with women without migraine history, women who reported active migraine with aura had an increased risk for major cardiovascular disease, ischemic stroke, myocardial infarction, coronary revascularization, angina, and death due to ischemic cardiovascular disease (Table 5) [88]. Patients who had prior migraine were at increased risk only of coronary revascularization and angina with respect to patients without migraine [88].

A further prospective cohort study of 20,084 men aged 40 to 84 years participating in the Physicians' Health Study showed, with a mean follow-up of 16 years, that migraine (any migraine including migraine with or without aura) was associated also in the male sex to an increased risk of cardiovascular disease. However, the detailed analysis of the end-point events showed that this overall increased risk was mainly driven by myocardial infarction while the risk of ischemic stroke, coronary revascularization, angina, and death due to ischemic cardiovascular disease was similar in migraineurs and non-migraineurs (Table 5) [89]. However, the association between migraine and ischemic stroke was modified by age $(P=0.03)$, indicating an increased risk of ischemic stroke for men with migraine who were 4054 years of age but not for those in the older age groups. In this study, information on aura was not available hindering any definitive conclusion about the possible different risk between male patients suffering from migraine with or without aura. A previous analysis of data from the same population [86] did not reveal the positive association found later $[88,89]$.

Mechanism linking migraine to cardiovascular and cerebrovascular diseases

Accordingly, solid evidence supports the concept that migraine, particularly migraine with aura is associated with ischemic stroke and ischemic heart disease. Although it is possible that in some individuals transient ischemic attacks were misclassified as aura, this seems unlikely to account for the increased risk. Moreover, triptan-induced chest pain might have been misdiagnosed with angina in some cases inducing a possible bias.

The mechanisms by which migraine either causes or cooccurs with cerebrovascular and cardiovascular disorders have remained cryptic and probably are rather complex. In the past, mechanisms relying on protracted cerebral vasoconstriction were postulated. Thereafter, an association between migraine with aura and congenital heart defects, particularly PFO, has been proposed as another potential mechanism accounting for the increased risk of stroke in migraineurs. Those possibilities, however, are unlikely to explain the association between migraine and coronary vascular events since they may explain the increased risk at the cerebral level only. More correctly, migraine can be considered a marker of a more wide systemic vascular disorder. In fact, there is increasing evidence that in migraineurs the vascular system not just in the brain but outside as well is impaired [95, 96]. Brachial artery diameter as brachial and femoral artery compliance were decreased while aortic augmentation index (a parameter of arterial stiffness that can be obtained from the central arterial waveform as the ratio of augmentation pressure by the reflection pressure wave to the pulse pressure) was increased in migraineurs [96]. Subjects with migraine had greater arterial stiffness than migraine-free subjects

Table 5 Multivariable-adjusted hazard ratios for ischemic vascular events according to migraine status in men and women according to data from the Women's Health Study [88] and the Physician's Health Study [89]

\begin{tabular}{lllllll}
\hline Event & \multicolumn{2}{l}{ Women; HR $(95 \% \mathrm{CI})$} & & \multicolumn{2}{l}{ Men; HR (95\% CI $)$} \\
\cline { 2 - 4 } & $\begin{array}{l}\text { No migraine } \\
(n=22,715)\end{array}$ & $\begin{array}{l}\text { Migraine with aura } \\
(n=1,434)\end{array}$ & $\begin{array}{l}\text { Migraine without aura } \\
(n=2,176)\end{array}$ & & $\begin{array}{l}\text { No migraine } \\
(n=18,635)\end{array}$ & $\begin{array}{l}\text { Any migraine } \\
(n=1,449)\end{array}$ \\
\hline Major cardiovascular event & 1 & $2.15(1.58-2.92) P<0.001$ & $1.23(0.88-1.73) P=0.23$ & 1 & $1.24(1.06-1.46) P=0.008$ \\
Ischemic stroke & 1 & $1.91(1.17-3.10) P=0.01$ & $1.27(0.77-2.09) P=0.36$ & 1 & $1.12(0.84-1.50) P=0.43$ \\
Myocardial infarction & 1 & $2.08(1.30-3.31) P=0.002$ & $1.22(0.73-2.05) P=0.45$ & 1 & $1.42(1.15-1.77) P<0.001$ \\
Coronary revascularization $P$ & 1 & $1.74(1.23-2.46) P=0.002$ & $0.98(0.67-1.42) P=0.90$ & 1 & $1.05(0.89-1.24) P=0.54$ \\
Angina & 1 & $1.71(1.16-2.53) P=0.007$ & $1.12(0.75-1.66) P=0.58$ & 1 & $1.15(0.99-1.33) P=0.07$ \\
Cardiovascular death & 1 & $2.33(1.21-4.51) P=0.01$ & $1.06(0.46-2.45) P=0.89$ & 1 & $1.07(0.80-1.43) P=0.65$ \\
\hline
\end{tabular}


independently of other confounding factors including age, sex, body height, blood pressure, and heart rate [97]. However, the precise mechanisms by which migraine may lead to cerebrovascular and cardiovascular events remain unclear. Several possibilities can be postulated to explain the increased risk in migraineurs.

The first hypothesis relies on the fact that the increased risk of vascular events can be due to a worst profile in terms of vascular risk factors of migraineurs, and particularly of migraineurs with aura, with respect to controls. The Genetic Epidemiology of Migraine (GEM) study reported that, compared to controls, migraineurs were more likely to smoke, less likely to consume alcohol, and more likely to report a parental history of early myocardial infarction [98]. Migraineurs with aura were more likely to have an unfavorable cholesterol profile, to have elevated blood pressure, to report a history of early onset coronary heart disease or stroke, and had an elevated Framingham risk score; female migraineurs with aura were more likely to be using oral contraceptives [98]. Moreover, migraine frequency and severity have been associated with increased body mass index [99] and migraine, particularly migraine with aura, has been associated with the methylenetetrahydrofolate reductase C677T genotype [100, 101], which may lead to hyperhomocysteinemia. Recently, compared with women with no migraine history, women who reported any history of migraine had modestly increased adjusted odds ratios for elevated total cholesterol, for non-HDL cholesterol, for apolipoprotein $\mathrm{B}_{100}$ and for $\mathrm{C}$-reactive protein [102]. The increase did not differ according to migraine aura status and migraine frequency. The same study did not find any association between migraine and LDL cholesterol, HDL cholesterol, apolipoprotein A-1, fibrinogen, soluble intercellular adhesion molecule-1, homocysteine, and creatinine [102]. However, the main limitation to the risk factors hypothesis is that in the above reported studies as in other studies most of the vascular risk factors were present in the multivariate model which showed the association between migraine and cerebrovascular and cardiovascular diseases [70, 88, 89, 103]. In addition, several studies indicated that the migraine-stroke association was present in the absence of traditional vascular risk factors and that the type of stroke was less frequently a large-vessel stroke or a small-vessel stroke with respect to the general stroke population [62, 104].

Migraine has also been associated to an increase in prothrombotic factors, including prothrombin factor [105, 106], factor V Leiden [107], and von Willebrand factor [108]. The role of those uncommon vascular risk factors remains to be clarified but probably they can be associated only with a minority of vascular events.

The second hypothesis postulates that migraine pathophysiology may affect the endothelial function and by this alone or in combination with existing local vascular pathologies may increase the vascular risk outside of a migraine attack. The dysfunction of the endothelium, a mechanical and biological barrier between the blood and the vascular wall, implies a change of its homeostatic properties in turn of procoagulatory, proinflammatory and proliferative state which predisposes to atherogenesis [109]. Endothelial dysfunction is characterized by reduction in bioavailability of vasodilators (such as nitric oxide), increase in endothelialderived contracting factors, and consequent impairment of the reactivity of the vasculature, including the microvasculature; it represents the first step in the development of atherothrombosis that finally leads to vascular events [109]. Traditional risk factors are known to cause endothelial dysfunction. There is also increasing evidence that migraine may be a non-traditional risk factor for endothelial dysfunction [95]. In fact, prothrombotic, proinflammatory, or other vasoactive peptides released during migraine may damage the endothelium, leading to an increased risk of atherosclerosis and vascular events. Endothelial dysfunction is mediated by increased oxidative stress, an important promotor of inflammatory processes [110]. Clinical investigation of markers of oxidative stress in a migraine population during, after, and between migraine attacks has yielded support for the association [111]. Moreover, cortical spreading depression, a self-propagating wave of neuronal and glial depolarization that has been implicated in the genesis of aura [112] might be responsible of cellular and molecular events, resulting in transient loss of membrane ionic gradients, as well as massive surges of extracellular potassium, neurotransmitters, and intracellular calcium. Cortical spreading depression may mediate its effects in part by altering the permeability of the blood-brain barrier via activation of matrix metalloproteinases, a family of neutral metalloproteases [113]. Their activation causes direct cellular damage and the release of vasoactive neuropeptides during migraine attacks that may stimulate inflammatory responses within and outside the brain [114]. Reduced endothelial repair capacity has emerged as another possible connection between migraine and vascular disease [115]. Levels of endothelial progenitor cells, measured using flow cytometry, were lower in migraineurs, and particularly in those with aura, with respect to healthy controls and to patients with tension-type headache; migraineurs presented also increased markers of senescence and decreased migratory capacity of endothelial progenitor cells. Endothelial progenitor cells derive from bone marrow, circulate in peripheral blood, are capable of proliferation and differentiation into endothelial cells, and play a role in neoangiogenesis after ischemia [116, 117]. Although it is not known if the reduction of endothelial progenitor cells represents a primary alteration in migraine or the consequence of migraine attacks, it might be possible that their alteration mediates the increased vascular risk. 
The third hypothesis is that a vasospastic disorder may give rise to both conditions. The finding in the ARIC study that migraine was associated with Rose angina but not with coronary artery disease suggests a further possible mechanism relying on a generalized vasospastic disorder underlying both migraine and angina [92]. This possibility is further supported by the finding that in women with indications for coronary angiography, those with migraine had less severe angiographic coronary artery disease than those without migraine [118]. Moreover, cases of nonatherosclerotic vasospam of the coronary arteries have been documented in migraineurs with cardiac symptoms [87, 89, 119].

The last hypothesis relies on an increased risk attributable to the different pharmacologic agents used to treat migraine. Concerns have been raised regarding the cardiovascular safety of the use of migraine medications, especially triptans and compounds containing ergotamine, due to their vasoconstrictive properties. However, recent reviews of the clinical, pharmacological and post-marketing cardiovascular safety data of triptans currently do not support a direct association of these drugs with ischemic vascular events [120, 121]. Moreover, data referring to the association between migraine and stroke date to the pre-triptans era. As migraine with and without aura is similarly treated, this hypothesis seems unlikely [122, 123].

\section{Conclusion}

Although migraine represents a clear vascular risk factor the odds of risk can be considered small, especially in the absence of concurrent vascular risk factors. To date, among the huge population of migraineurs it is not possible to recognize the subjects who will develop a vascular event. It is currently unclear whether specific migraine features, such as frequency or intensity, are associated with further high risk of vascular events. In addition, it is currently unknown if the treatment of migraine reduces the risk of ischemic vascular events.

Nonetheless, for patients with migraine with aura, we recommend heightened vigilance for and active control of cardiovascular risk factors such as hypertension, hyperlipidemia, and smoking. Particular caution should be applied in prescribing combined oral contraceptives in patients with migraine with aura especially when they have additional risk factors which cannot easily be controlled [124]. Future studies should investigate the possibility that preventive medications for migraine or antiplatelet treatments might modify the risk of vascular disease in subjects with migraine and whether there are subgroups most likely to benefit [123].
Conflict of interest None.

\section{References}

1. Feinstein AR (1970) The pre-therapeutic classification of comorbidity in chronic disease. J Chronic Dis 23:455-468

2. Lipton RB, Silberstein SD (1994) Why study the comorbidity of migraine? Neurology 44(suppl 7):S4-S5

3. Sacco S, Olivieri L, Bastianello S, Carolei A (2006) Comorbid neuropathologies in migraine. J Headache Pain 7:222-230

4. Meier B, Lock JE (2003) Contemporary management of patent foramen ovale. Circulation 107:5-9

5. Sommer RJ, Hijazi ZM, Rhodes JF (2008) Pathophysiology of congenital heart disease in the adult. Part I: shunt lesions. Circulation 117:1090-1099

6. Anzola GP, Magoni M, Guindani M, Rozzini L, Dalla Volta G (1999) Potential source of cerebral embolism in migraine with aura: a transcranial Doppler study. Neurology 52:1622-1625

7. Dalla Volta G, Guindani M, Zavarise P, Griffini S, Pezzini A, Padovani A (2005) Prevalence of patent foramen ovale in a large series of patients with migraine with aura, migraine without aura and cluster headache, and relationship with clinical phenotype. J Headache Pain 6:328-330

8. Del Sette M, Angeli S, Leandri M, Ferriero G, Buzzone GL, Finocchi C, Gandolfo C (1998) Migraine with aura and right-toleft shunt on transcranial Doppler: a case-control study. Cerebrovasc Dis 8:327-330

9. Ferrarini G, Malferrari G, Zucco R, Gaddi O, Norina M, Pini LA (2005) High prevalence of patent foramen ovale in migraine with aura. J Headache Pain 6:71-76

10. Jesurum JT, Fuller CJ, Velez CA, Spencer MP, Krabill KA, Likosky WH, Gray WA, Olsen JV, Reisman M (2007) Migraineurs with patent foramen ovale have larger right-to-left shunt despite similar atrial septal characteristics. J Headache Pain 8:209-216

11. Lamy C, Giannesini C, Zuber M, Arquizan C, Meder JF, Trystram D, Coste J, Mas JL (2002) Clinical and imaging findings in cryptogenic stroke patients with and without patent foramen ovale. The PFO-ASA study. Stroke 33:706-711

12. Mas JL, Arquizan C, Lamy C, Zuber M, Cabanes L, Derumeaux G, Coste J, for the Patent Foramen Ovale, Atrial Septal Aneurysm Study Group (2001) Recurrent cerebrovascular events associated with patent foramen ovale, atrial septal aneurysm or both. N Engl J Med 345:1740-1746

13. Sztajzela R, Genouda D, Rotha S, Mermillodb B, Le FlochRohra J (2002) Patent foramen ovale, a possible cause of symptomatic migraine. A study of 74 patients with acute ischemic stroke. Cerebrovasc Dis 13:102-106

14. Wilmshurst P, Nightingale S (2006) The role of cardiac and pulmonary pathology in migraine: a hypothesis. Headache 46:429-434

15. Tembl J, Lago A, Sevilla T, Solis P, Vilchez J (2007) Migraine, patent foramen ovale and migraine triggers. J Headache Pain $8: 7-12$

16. Anzola GP, Meneghetti G, Zanferrari C, Adami A, Dinia L, Del Sette M, for the SAM Study Group (2008) Is migraine associated with right-to-left shunt a separate disease? Results of the SAM study. Cephalalgia 28:360-366

17. Anzola GP, Frisoni GB, Morandi E, Casilli F, Onorato E (2006) Shunt associated migraine responds favorably to atrial septal repair: a case control study. Stroke 37:430-434

18. Anzola GP, Morandi E, Casilli F, Onorato E (2006) Different degrees of right-to-left shunting predict migraine and stroke: data from 420 patients. Neurology 66:765-767 
19. Azarbal B, Tobis J, Suh W, Chan V, Dao C, Gaster R (2005) Association of interatrial shunts and migraine headaches: impact of transcatheter closure. J Am Coll Cardiol 45:489-492

20. Giardini A, Donti A, Formigari R, Salomone L, Prandstraller D, Bonvicini M, Palareti G, Guidetti D, Gaddi O, Picchio FM (2006) Transcatheter patent foramen ovale closure mitigates aura migraine headaches abolishing spontaneous right-to-left shunting. Am Heart J 151:922e1-922e5

21. Kimmelstiel C, Gange C, Thaler D (2007) Is patent foramen ovale closure effective in reducing migraine symptoms? A controlled study. Catheter Cardiovasc Interv 69:740-746

22. Morandi E, Anzola GP, Angeli S, Melzi G, Onorato E (2003) Transcatheter closure of patent foramen ovale: a new migraine treatment? J Interv Cardiol 16:39-42

23. Post MC, Thijs V, Herroelen L, Budts WI (2004) Closure of a patent foramen ovale is associated with a decrease in prevalence of migraine. Neurology 62:1439-1440

24. Reisman M, Christofferson RD, Jesurum J, Olsen JV, Spencer MP, Krabill KA, Diehl L, Aurora S, Gray WA (2005) Migraine headache relief after transcatheter closure of patent foramen ovale. J Am Coll Cardiol 45:493-495

25. Rigatelli G, Cardaioli P, Braggion G, Giordan M, Fabio D, Aggio S, Roncon L, Chinaglia M (2007) Resolution of migraine by transcatheter patent foramen ovale closure with Premere Occlusion System in a preliminary series of patients with previous cerebral ischemia. Catheter Cardiovasc Interv 70:429-433

26. Schwedt T, Dodick D (2006) Patent foramen ovale and migraine: bringing closure to the subject. Headache 46:663-671

27. Schwerzmann M, Wiher S, Nedeltchev K, Mattle HP, Wahl A, Seiler C, Meier B, Windecker S (2004) Percutaneous closure of patent foramen ovale reduces the frequency of migraine attacks. Neurology 62:1399-1401

28. Wilmshurst P, Bryson P (2000) Relationship between the clinical features of neurological decompression illness and its causes. Clin Sci (Lond) 99:65-75

29. Wilmshurst PT, Nightingale S, Walsh KP, Morrison WL (2000) Effect on migraine of closure of cardiac right-to-left shunts to prevent recurrence of decompression illness or stroke or for haemodynamic reasons. Lancet 356:1648-1651

30. Dowson AJ, Mullen M, Peatfield R, Muir K, Khan A, Wells C, Lipscombe S, Rees T, De Giovanni J, Morrison W, HildickSmith D, Elrington G, Hillis W, Malik I, Rickards A (2008) Migraine Intervention with STARFlex Technology trial: a prospective, multicentre, double-blind, sham-controlled trial to evaluate the effectiveness of patent foramen ovale closure with STARFlex septal repair implant to resolve refractory migraine headache. Circulation 117:1397-1404

31. Silberstein SD (2005) Topiramate in migraine prevention. Headache 45(suppl 1):S57-S65

32. Diener HC, on behalf of the Council of the European Headache Federation (2007) Patent foramen ovale and migraine: no reason to intervene. J Headache Pain 8:3-6

33. Cirillo M, Stellato D, Lombardi C, De Santo NG, Covelli V (1999) Headache and cardiovascular risk factors: positive association with hypertension. Headache 39:409-416

34. Franceschi M, Colombo B, Rossi P, Canal N (1997) Headache in a population-based elderly cohort. An ancillary study to the Italian Longitudinal Study of Aging (ILSA). Headache 37:79-82

35. Marcoux S, Berube S, Brisson J, Fabia J (1992) History of migraine and risk of pregnancy-induced hypertension. Epidemiology 3:53-56

36. Markush RE, Karp HR, Heyman A, O'Fallon WM (1975) Epidemiologic study of migraine symptoms in young women. Neurology 25:430-435

37. Merikangas KR, Fenton BT (1994) Comorbidity of migraine with somatic disorders in a large-scale epidemiologic study in the United States. In: Olesen J (ed) Headache classification and epidemiology. Raven Press, New York, pp 301-314

38. Chen TC, Leviton A, Edelstein S, Ellenberg JH (1987) Migraine and other diseases in women of reproductive age. The influence of smoking on observed associations. Arch Neurol 44:10241028

39. Gudmundsson LS, Thorgeirsson G, Sigfusson N, Sigvaldason H, Johannsson M (2005) Migraine patients have lower systolic but higher diastolic blood pressure compared with controls in a population-based study of 21,537 subjects. The Reykjavik Study. Cephalalgia 26:436-444

40. Hagen K, Stovner LJ, Vatten L, Holmen J, Zwart J-A, Bovim G (2002) Blood pressure and risk of headache: a prospective study of 22,685 adults in Norway. J Neurol Neurosurg Psychiatry 72:463-466

41. Muiesan ML, Padovani A, Salvetti M, Monteduro C, Poisa P, Bonzi B, Paini A, Cottini E, Agosti C, Castellano M, Rizzoni D, Vignolo A, Agabiti-Rosei E (2006) Headache: prevalence and relationship with office or ambulatory blood pressure in a general population sample (the Vobarno Study). Blood Press 15:1419

42. Prudenzano MP, Monetti C, Merico L, Cardinali V, Genco S, Lamberti P, Livrea P (2005) The comorbidity of migraine and hypertension. A study in a tertiary care headache centre. J Headache Pain 6:220-222

43. Rasmussen BK, Olesen J (1992) Symptomatic and nonsymptomatic headaches in a general population. Neurology 42:12251231

44. Tronvik E, Stovner LJ, Hagen K, Holmen J, Zwart JA (2008) High pulse pressure protects against headache: prospective and cross-sectional data (HUNT study). Neurology 70:1329-1336

45. Waters WE (1971) Headache and blood pressure in the community. BMJ 1:142-143

46. Tzourio C, Gagniere B, El Amrani M, Alperovitch A, Bousser MG (2003) Relationship between migraine, blood pressure and carotid thickness. A population-based study in the elderly. Cephalalgia 23:914-920

47. Wiehe M, Fuchs SC, Moreira LB, Stoll Moraes R, Fuchs FD (2002) Migraine is more frequent in individuals with optimal and normal blood pressure: a population-based study. J Hypertens 20:1303-1306

48. Schrader H, Stovner LJ, Helde G, Sand T, Bovim G (2001) Prophylactic treatment of migraine with angiotensin converting enzyme inhibitor (lisinopril): randomised, placebo controlled, crossover study. BMJ 322:19-23

49. Tronvik E, Stovner LJ, Helde G, Sand T, Bovim G (2003) Prophylactic treatment of migraine with an angiotensin II receptor blocker: a randomized controlled trial. JAMA 289:6569

50. Charles JA, Jotkowitz S, Byrd LH (2006) Prevention of migraine with olmesartan in patients with hypertension/prehypertension. Headache 46:503-507

51. Bousser MG, Welch KMA (2005) Relation between migraine and stroke. Lancet Neurol 4:533-542

52. Buring JE, Hebert P, Romero J, Kittross A, Cook N, Manson J, Peto R, Hennekens C (1995) Migraine and subsequent risk of stroke in the Physicians' Health Study. Arch Neurol 52:129 134

53. Carolei A, Marini C, De Matteis G, the Italian National Research Council Study Group of Stroke in the Young (1996) History of migraine and risk of cerebral ischaemia in young adults. Lancet 347:1503-1506

54. Chang CL, Donaghy M, Poulter N (1999) Migraine and stroke in young women: case-control study. The World Health Organisation Collaborative Study of Cardiovascular Disease and Steroid Hormone Contraception. BMJ 318:13-18 
55. Collaborative Group for the Study of Stroke in Young Women (1975) Oral contraceptives and stroke in young women. JAMA 231:718-722

56. Donaghy M, Chang CL, Poulter N (2002) Duration, frequency, recency, and type of migraine and the risk of ischaemic stroke in women of childbearing age. J Neurol Neurosurg Psychiatry 73:747-750

57. Etminan M, Takkouche B, Isorna FC, Samii A (2005) Risk of ischaemic stroke in people with migraine: systematic review and meta-analysis of observational studies. BMJ 330:63-65

58. Haapaniemi H, Hillbom M, Juvela S (1997) Life-style associated risk factors for acute brain infarction among persons of working age. Stroke 28:26-30

59. Henrich JB, Horwitz RI (1989) A controlled study of ischemic stroke risk in migraine patients. J Clin Epidemiol 42:773-780

60. Kurth T, Slomke MA, Kase CS, Cook NR, Lee IM, Gaziano JM, Diener HC, Buring JE (2005) Migraine, headache, and the risk of stroke in women: a prospective study. Neurology 64:10201026

61. Lidegaard O (1995) Oral contraceptives, pregnancy and the risk of cerebral thromboembolism: the influence of diabetes, hypertension, migraine and previous thrombotic disease. $\mathrm{Br} \mathrm{J}$ Obstet Gynaecol 102:153-159

62. MacClellan LR, Giles W, Cole J, Wozniak M, Stern B, Mitchell BD, Kittner SJ (2007) Probable migraine with visual aura and risk of ischemic stroke: The Stroke Prevention in Young Women Study. Stroke 38:2438-2445

63. Marini C, Carolei A, Roberts RS, Prencipe M, Gandolfo C, Inzitari D et al (1993) Focal cerebral ischemia in young adults: a collaborative case-control study. Neuroepidemiology 12:70-81

64. Merikangas KR, Fenton BT, Cheng SH, Stolar MJ, Risch N (1997) Association between migraine and stroke in a large-scale epidemiological study of the United States. Arch Neurol 54:362-368

65. Milhaud D, Bogousslavsky J, van Melle G, Liot P (2001) Ischemic stroke and active migraine. Neurology 57:1805-1811

66. Mosek A, Marom R, Korczyn AD, Bornstein N (2001) A history of migraine is not a risk factor to develop an ischemic stroke in the elderly. Headache 41:399-401

67. Nightingale AL, Farmer RD (2004) Ischemic stroke in young women: a nested case-control study using the UK general practice research database. Stroke 35:1574-1578

68. Schwaag S, Nabavi DG, Frese A, Husstedt IW, Evers S (2003) The association between migraine and juvenile stroke: a casecontrol study. Headache 43:90-95

69. Sochurkova D, Moreau T, Lemesle M, Menassa M, Giroud M, Dumas R (1999) Migraine history and migraine-induced stroke in the Dijon stroke registry. Neuroepidemiology 18:85-91

70. Stang PE, Carson AP, Rose KM, Mo J, Ephross SA, Shahar E, Szklo M (2005) Headache, cerebrovascular symptoms, and stroke: the Atherosclerosis Risk in Communities Study. Neurology 64:1573-1577

71. Tzourio C, Iglesias S, Hubert JB, Visy JM, Alpérovitch A, Tehindrazanarivelo A, Biousse V, Woimant F, Bousser MG (1993) Migraine and risk of ischaemic stroke: a case-control study. $\mathrm{Br}$ Med J 307:289-292

72. Tzourio C, Tehindrazanarivelo A, Iglesias S et al (1995) Casecontrol study of migraine and risk of ischaemic stroke in young women. Br Med J 310:830-833

73. Headache Classification Subcommittee of the International Headache Society. The International Headache Classification of Headache Disorders, 2nd edn (2004) Cephalalgia 24(suppl 1):9160

74. Kruit MC, van Buchem MA, Hofman PA, Bakkers JT, Terwindt GM, Ferrari MD, Launer LJ (2004) Migraine as a risk factor for subclinical brain lesions. JAMA 291:427-434
75. Kruit MC, Launer LJ, Ferrari MD, van Buchem MA (2005) Infarcts in the posterior circulation territory in migraine. The population-based MRI CAMERA study. Brain 128:2068-2077

76. Bogousslavsky J, Regli F, Van Melle G, Payot M, Uske A (1988) Migraine stroke. Neurology 38:223-227

77. Broderick JP, Swanson JW (1987) Migraine-related strokes. Clinical profile and prognosis in 20 patients. Arch Neurol 44:868-871

78. Caplan LR (1991) Migraine and vertebrobasilar ischemia. Neurology 41:55-61

79. Milhaud D, Bogousslavsky J, Van Melle G, Liot P (2001) Ischemic stroke and active migraine. Neurology 57:1805-1811

80. Coppeto JR, Lessell S, Sciarra R, Bear L (1986) Vascular retinopathy in migraine. Neurology 36:267-270

81. Newman NJ, Lessell S, Brandt EM (1989) Bilateral central retinal artery occlusions, disk drusen, and migraine. Am J Ophthalmol 107:236-240

82. Beversdorf D, Stommel E, Allen C, Stevens R, Lessell S (1997) Recurrent branch retinal infarcts in association with migraine. Headache 37:396-399

83. Glenn AM, Shaw PJ, Howe JW, Bates D (1992) Complicated migraine resulting in blindness due to bilateral retinal infarction. Br J Ophthalmol 76:189-190

84. Liew G, Mitchell P, Wong TY, Wang JJ (2006) Retinal vascular caliber and migraine: the Blue Mountains Eye Study. Headache 46:997-1004

85. Rose KM, Wong TY, Carson AP, Couper DJ, Klein R, Sharrett AR (2007) Migraine and retinal microvascular abnormalities: The Atherosclerosis Risk in Communities Study. Neurology 68:1694-1700

86. Cook NR, Benseñor IM, Lotufo PA (2002) Migraine and coronary heart disease in women and men. Headache 42:715727

87. Fournier JA, Fernandez-Cortacero JA, Granado C, Gascon D (1986) Familial migraine and coronary artery spasm in two siblings. Clin Cardiol 9:121-125

88. Kurth T, Gaziano JM, Cook NR, Logroscino G, Diener H, Buring JE (2006) Migraine and risk of cardiovascular disease in women. JAMA 296:283-291

89. Kurth T, Gaziano JM, Cook NR, Bubes V, Logroscino G, Diener $\mathrm{H}$, Buring JE (2007) Migraine and risk of cardiovascular disease in men. Arch Int Med 167:795-801

90. Lafitte C, Even C, Henry-Lebras F, de Toffol B, Autret A (1996) Migraine and angina pectoris by coronary artery spasm. Headache 36:332-334

91. Mitchell P, Wang JJ, Currie J, Cumming RG, Smith W (1998) Prevalence and vascular associations with migraine in older Australians. Aust N Z J Med 28:627-632

92. Rose KM, Carson AP, Sanford CP, Stang PE, Brown CA, Folsom AR, Szklo M (2004) Migraine and other headaches: associations with Rose angina and coronary heart disease. Neurology 63:2233-2239

93. Sternfeld B, Stang P, Sidney S (1995) Relationship of migraine headaches to experience of chest pain and subsequent risk for myocardial infarction. Neurology 45:2135-2142

94. Wayne VS (1986) A possible relationship between migraine and coronary artery spasm. Aust N Z J Med 16:708-710

95. Tietjen GE (2007) Migraine and ischaemic heart disease and stroke: potential mechanisms and treatment implications. Cephalalgia 27:981-987

96. Vanmolkot FH, Van Bortel LM, de Hoon JN (2007) Altered arterial function in migraine of recent onset. Neurology 68:1563-1570

97. Nagai T, Tabara Y, Igase M, Nakura J, Miki T, Kohara K (2007) Migraine is associated with enhanced arterial stiffness. Hypertens Res 30:577-583 
98. Scher AI, Terwindt GM, Picavet HS, Verschuren WM, Ferrari MD, Launer LJ (2005) Cardiovascular risk factors and migraine: the GEM population-based study. Neurology 64:614-620

99. Bigal ME, Liberman JN, Lipton RB (2006) Obesity and migraine: a population study. Neurology $66: 545-550$

100. Lea RA, Ovcaric M, Sundholm J, Solyom L, Macmillan J, Griffiths LR (2005) Genetic variants of angiotensin converting enzyme and methylenetetrahydrofolate reductase may act in combination to increase migraine susceptibility. Brain Res Mol Brain Res 136:112-117

101. Scher AI, Terwindt GM, Verschuren WM, Kruit MC, Blom HJ, Kowa H, Frants RR, van den Maagdenberg AM, van Buchem M, Ferrari MD, Launer LJ (2006) Migraine and MTHFR C677T genotype in a population-based sample. Ann Neurol 59:372-375

102. Kurth T, Ridker PM, Buring JE (2007) Migraine and biomarkers of cardiovascular disease in women. Cephalalgia 28:49-56

103. Rosamond W (2004) Are migraine and coronary heart disease associated? An epidemiologic review. Headache 44:S5-S12

104. Yoon G, Baggaley S, Bacchetti P, Fu YH, Digre KB, Ptácek LJ (2005) Clinic-based study of family history of vascular risk factors and migraine. J Headache Pain 6:412-416

105. Goadsby PJ, Lipton RB, Ferrari MD (2002) Migraine - current understanding and treatment. N Engl J Med 346:257-270

106. Silberstein SD (2004) Migraine. Lancet 363:381-391

107. Soriani S, Borgna-Pignatti C, Trabetti E, Casartelli A, Montagna P, Pignatti PF (1998) Frequency of factor V Leiden in juvenile migraine with aura. Headache 38:779-781

108. Tietjen GE, Al-Qasmi MM, Athanas K, Dafer RM, Khuder SA (2001) Increased von Willebrand factor in migraine. Neurology $57: 334-336$

109. Ross R (1999) Atherosclerosis-an inflammatory disease. Lancet 340:115-126

110. Bonetti PO, Lerman LO, Lerman A (2003) Endothelial dysfunction: a marker of atherosclerotic risk. Arterioscler Thromb Vasc Biol 23:168-175

111. Ciancarelli I, Tozzi-Ciancarelli MG, Di Massimo C, Marini C, Carolei A (2003) Urinary nitric oxide metabolites and lipid peroxidation by-products in migraine. Cephalalgia 23:39-42

112. Moskowitz MA, Macfarlane R (1993) Neurovascular and molecular mechanisms in migraine headaches. Cerebrovasc Brain Metab Rev 5:159-177
113. Gursoy-Ozdemir Y, Qiu J, Matsuoka N, Bolay H, Bermpohl D, Jin H, Wang X, Rosenberg GA, Lo EH, Moskowitz MA (2004) Cortical spreading depression activates and up-regulates MMP9. J Clin Invest 113:1447-1455

114. Waeber C, Moskowitz MA (2005) Migraine as an inflammatory disorder. Neurology 64(suppl 2):S9-S15

115. Lee ST, Chu K, Jung KH, Kim DH, Kim EH, Choe VN, Kim JH, Im WS, Kang L, Park JE, Park HJ, Park HK, Song EC, Lee SK, Kim M, Roh JK (2008) Decreased number and function of endothelial progenitor cells in patients with migraine. Neurology 70:1510-1517

116. Asahara T, Murohara T, Sullivan A, Silver M, van der Zee R, Li T, Witzenbichler B, Schatteman G, Isner JM (1997) Isolation of putative progenitor endothelial cells for angiogenesis. Science 275:964-967

117. Werner N, Kosiol S, Schiegl T, Ahlers P, Walenta K, Link A, Böhm M, Nickenig G (2005) Circulating endothelial progenitor cells and cardiovascular outcomes. N Engl J Med 353:999-1007

118. Ahmed B, Bairey Merz CN, McClure C, Johnson BD, Reis SE, Bittner V, Pepine CJ, Sharaf BL, Sopko G, Kelsey SF, Shaw L, WISE Study Group (2006) Migraines, angiographic coronary artery disease and cardiovascular outcomes in women. Am J Med 119:670-675

119. Hoffmann M (2006) Stroke and chest pain in young people with migraine. Headache 46:208-211

120. Dodick DW, Martin VT, Smith T, Silberstein S (2004) Cardiovascular tolerability and safety of triptans: a review of clinical data. Headache 44:S20-S30

121. Hall GC, Brown MM, Mo J, MacRae KD (2004) Triptans in migraine: the risks of stroke, cardiovascular disease, and death in practice. Neurology 62:563-568

122. Lipton RB, Bigal ME (2006) Migraine and cardiovascular disease. JAMA 296:332-333

123. Lipton RB, Bigal ME (2007) Migraine and cardiovascular disease: is there a link? Nat Clin Pract Neurol 3:74-75

124. Bousser MG, Conard J, Kittner S, de Lignières B, MacGregor EA, Massiou H, Silberstein SD, Tzourio C (2000) Recommendations on the risk of ischaemic stroke associated with use of combined oral contraceptives and hormone replacement therapy in women with migraine. Cephalalgia 20:155-156 